\title{
Yüksek Yağlı Diyet ile Beslenen Ratlarda Mate (Ilex paraguariensis) Çayının Obeziteyi Önleyici Etkisinin Histopatolojik ve Biyokimyasal Olarak Araştırılması
}

\author{
Ahmet UYAR ${ }^{1 *}$, Erhan ESIM ${ }^{2}$ \\ ${ }^{1}$ Mustafa Kemal Üniversitesi, Veteriner Fakültesi, Patoloji Anabilim Dalı, Hatay, Türkiye. \\ ${ }^{2}$ Yüzüncü Yıl Üniversitesi, Veteriner Fakültesi, Patoloji Anabilim Dalı, Van, Türkiye.
}

Geliş Tarihi: 02.05.2018

Kabul Tarihi: 19.11.2018

\begin{abstract}
Özet: Bu çalışmada yüksek yağlı diyetle beslenen ratlarda, Mate yaprağı (Ilex paraguariensis) çayının obezite oluşumu üzerine etkisi histopatolojik ve biyokimyasal olarak araştırıldı. Bu amaçla 32 adet Wistar albino rat; Kontrol (K) (n: 8), Yüksek Yağıı Diyet (YYD) (n: 8), YYD+Mate (YYD+M) (n: 8) ve Mate (M) (n: 8) olmak üzere 4 gruba ayrıldı. Kontrol grubu ratlar standart pelet yemle beslendi. YYD ve YYD+M grubu ratlara, $300 \mathrm{~g} / \mathrm{kg}$ oranında tereyağı eritilip yeme katılarak enerji değeri yüksek (4165 kcal/kg) hale getirilen pelet yem verildi. YYD+M ve $M$ grubu ratlar ise $3 \mathrm{gr} / \mathrm{kg}$ vücut ağırlığı olacak şekilde günlük hazırlanan Mate yaprağı (Ilex paraguariensis) çayı orogastrik sonda ile verildi. Çalışma süresince ratların canlı ağırlık artışları izlendi. Histopatolojik olarak karaciğerlerden alınan doku örneklerinde YYD grubunda yağlanma, hidropik dejenerasyon ve bazı hepatositlerde koagulasyon nekrozları görülürken, YYD+M grubunda tek tük yağlanma görüldü. Biyokimyasal analizlerde ALT, AST, ALP, LDH, GGT, kolesterol, trigliserit, HDL ve açlık kan glukoz düzeyleri YYD grubunda kontrol grubuna göre belirgin düzeyde yüksek, YYD+M grubunda ise kontrol grubuna yakın olduğu tespit edildi. Sonuç olarak, YYD ile birlikte verilen Mate yaprağı (Ilex paraguariensis) çayının ratlarda obezite oluşumunun önüne geçebileceği kanaatine varıldı.
\end{abstract}

Anahtar Kelimeler: Antiobesite etki, Mate, Yüksek yağlı diyet.

\section{Histopathological and Biochemical Investigation of the Effects of Mate (Ilex paraguariensis) Tea on Antiobesity Effect in Rats Fed with High Fat Diet}

\begin{abstract}
The aim of this study was to investigate the preventative effect of Mate tea (llex paraguariensis) tea on obesity development in rats fed with high fat diet by histopathological and biochemical methods. In this study, 32 Wistar albino rats were divided into four groups as Control Group (C) (n:8), High Fat Diet Group (YYD) (n: 8), High Fat Diet+Mate Group (YYD+M) (n: 8) and Mate Group (M) (n: 8). YYD and YYD+M group rats received YYD (4165 kcal/kg) containing fat $(300 \mathrm{~g} / \mathrm{kg})$ for 8 weeks. The daily preparation of Mate leaf (Ilex paraguariensis) tea at the dose of $3 \mathrm{~g} / \mathrm{kg}$ body weight in rats of group YYD+M and M group was given by orogastric catheter. During the study, weight gain of the rats was monitored. Hepatoprotective effect by llex paraguariensis tea was further supported by the almost normal histology in YYD+M group as compared to the degenerative changes such as fattenings, hydropic degeneration and coagulation necrosis of some hepatocyte in the YYD treated rats. Decreased levels of blood glucose AST, ALT, ALP, LDH, GGT, cholesterol, triglycerides, HDL cholesterol and glocose were detected in YYD+M group. These findings suggested that simultaneous treatment of llex paraguariensis attenuated hepatic fat accumulation in YYD fed rats.
\end{abstract}

Keywords: Antiobesity effect, High-fat diet, Ilex paraguariensis.

\section{Giriş}

Kentleşme ve sanayileşme, insanların yaşam tarzında obeziteye yatkınlık oluşturabilecek önemli değişikliklere neden olmuştur. Fiziksel aktivitenin azalması, yiyeceklerin kolay ulaşılabilir, bol ve ucuz olması bu değişikliklerin başlıcalarıdır. Hızlı yemek yeme alışkanlığı, hazır gıda tüketiminin artması ve yiyecek maddelerinin yüksek oranda yağ ve şeker içermesi fazla kalori alımını artırmaktadır (Bell ve ark., 2005). Enerji yönünden zengin gıda tüketimi ve fiziksel aktivite eksikliği nedeniyle günümüzde aşırı kilolu/obez kişi sayısı artmıştır. Dünya Sağlık
Örgütü (WHO) raporlarında obezitenin 1980 yılından sonra 2 kat arttığı, 2008 yılında ise 1.8 milyar insanın aşırı kilolu, 500 milyon insanın ise obez olduğu bildirilmiştir. 2012 yılı için 5 yaş altındaki 42 milyon çocuğun aşırı kilolu ya da obez olduğu rapor edilmiştir (Adıyaman, 2016).

Kandaki yüksek kolesterol düzeyini düşürmek ve buna bağlı olarak oluşan patolojileri önlemek amacıyla medikal uygulamalar (statinler) ve diyet gibi yöntemler kullanılmaktadır. Bu amaçla sibutramin ve orlistat adlı iki farklı ilaç 
kıllanılmaktadır. Bu amaçla kullanılan Amerikan Gıda ve İlaç Dairesi (FDA) tarafından onaylı sibutramin ve orlistat adlı iki farklı ilaç bulunmaktadır. Ancak bu ilaçların kullanımına bağlı olarak kilo kaybı orta derecededir (Pagotto ve ark., 2008). Kilo kaybının orta derecede olması ve medikal uygulamalarda kullanılan orlistat ve sibutraminin yan etkilerinin fazla olması insanları oldukça rağbet gören alternatif tıbba yönlendirmiştir. Bütün dünya ülkelerinde olduğu gibi ülkemizde de bitkisel yöntemler oldukça rağbet görmektedir. Yan etkilerinin az olması, kullanım kolaylığı, kolay bulunabilmesi özellikle bitkisel seçeneklerin tercih edilmesinde etkili olmuştur (Padwal ve Majumdar, 2007). Tüm dünyada olduğu gibi ülkemizde de Mate olarak bilinen "llex paraguariensis" bitkisi, kilo alımını engellemek veya kilo vermek amacıyla çay şeklinde kullanılan bitkilerdendir (Baytop, 1994). Şili, Peru, Arjantin, Brezilya ve Çin gibi ülkelerde doğal olarak yetişmekte olan Mate bitkisi (Evans, 2009; Padwal ve Majumdar, 2007), ülkemizde Trabzon-Maçka bölgesinde yetişmektedir (Baytop, 1994; Davis, 1967). Dünyanın değişik bölgelerinde hierba mate, yerba mate, erva maté, kaiha, chimarrao ve tereré (Bracesco ve ark., 2001), Jesuit's Brazil Çayı, St. Bartholomew's çayı, Paraguay çayı (LaGow, 2004), Mate ve Hervea (Wichtl, 2004) gibi isimlerle bilinmektedir. I. paraguariensis bitkisinin üzerinde yapılan çalışmalarda bu bitkinin kimyasal bileşeninde özellikle fenolik asitler, flavon ve flavonoller, saponinler (Arçari ve ark., 2011), pürin alkaloitleri, kateşik tanenler, klorojenik asit ve türevleri (Bastos ve ark., 2007), kafeik asit (Anesini ve ark., 2012; Arçari ve ark., 2011) tespit edilmiştir. Halk arasında vücuda zindelik vermek ve vücuttan su atılımını artırarak zayıflama amaçlı kullanılmasının yanısıra (Davis, 1967), ülser ve enflamasyona karşı krem (Vieira, 2008) haricen lapa şeklinde de kullanılmaktadır (LaGow, 2004). Yapılan bilimsel çalışmalarda bu bitkinin; antioksidan (Filip ve ark., 2000), antienflamatuvar (Arçari ve ark., 2011), antimikrobiyal (Martin ve ark., 2013), antidepresan (Reis ve ark., 2014), antiromatizmal (Newall ve Anderson, 1996) ve sitotoksik (Mejia ve ark., 2010; Ramirez-Mares ve ark., 2004) etkilere sahip olduğu kanıtlanmıştır. Bitki bu özellikleri nedeniyle; selülite ve yaşlanmaya karşı (Bracesco ve ark., 2001), gastrointestinal problemlerde (LaGow, 2004), zihinsel ve fiziksel yorgunlukta (Blumenthal, 1998), açlık ve susuzluk hissini gidermede (Andersen ve Fogh, 2001) kullanılmıştır. Mate'nin normal dozlarda kullanıldığında herhangi bir probleme neden olmadığı, ancak çok fazla tüketildiğinde, korku ve gerginlik durumları gibi psikolojik yan etkilere, uykusuzluğa ve palpitasyona sebep olduğu bildirilmiştir (Çubukçu ve ark., 2002).

$\mathrm{Bu}$ çalışmada yüksek yağlı diyet ile beslenen ratlarda Mate (Ilex paraguariensis) çayının obeziteyi önleyici etkisi histopatolojik ve biyokimyasal olarak araştırıldı.

\section{Materyal ve Metot}

Deney hayvanları: Yerel Etik Kurulu'ndan gerekli izin (2015/14) alındıktan sonra Van Yüzüncü Yıl Üniversitesi Deneysel Araştırmalar Birimi'nden ortalama 260-285 gr ağırlığında Wistar-albino türü 32 adet rat temin edildi. Deneme süresince $12 ; 12$ saat aydınlık/karanlık ışıklandırılması, $22 \pm 2{ }^{\circ} \mathrm{C}$ ısısı, $\% 45-50$ nemi otomatik olarak ayarlanmış odalarda barındırılan ratlar için yem ve su alımı serbest (ad libitum) bırakıldı. Ratlar çalışma başlangıcında tartılarak ağırlık bakımından eşit dağılımlı olacak şekilde gruplara ayrıldı.

Bitki materyali ve yüksek yağı diyet (YYD) hazırlanması: Bitki materyali olarak Smart Kimya Tic. ve Danışmanlık Ltd. Şti. (Hammaddeler.com)'den temin edilen Mate yaprağı (Ilex paraguariensis) kullanıldı. Günlük olarak uygulama öncesinde $3 \mathrm{gr} / \mathrm{kg}$ vücut ağırlığı dozda Mate yaprağı çayı 8'er rat için hesaplanarak herbir rat için $2 \mathrm{ml} / \mathrm{kg}$ oral yoldan verilecek şekilde toplam $50 \mathrm{ml}$ distile suda bir homojenizatör yardmıyla hazırlandı (Arçari ve ark., 2009). Ticari bir yem üreticisinden temin edilen standart pelet yem öğütüldükten sonra $300 \mathrm{~g} / \mathrm{kg}$ oranında tereyağı eritilip yeme katılarak enerji değeri (4165 $\mathrm{kcal} / \mathrm{kg}$ ) yüksek hale getirilen pelet yem haftalık olarak hazırlandı (Gunbatar ve Bayiroglu, 2014). Çalışmada kullanılan rat yemi içerikleri ve enerji değeri Tablo 1'de sunulmuştur.

Tablo 1. Çalışmada kullanılan rat yemi içerikleri ve enerji değeri.

\begin{tabular}{ll}
\hline Enerji (kcal/kg) & 4165 \\
Ham yağ (\%) & 41.56 \\
Ham protein (\%) & 18.45 \\
Ham selüloz (\%) & 6.72 \\
Ham kül (\%) & 5.46 \\
\hline
\end{tabular}

Grupların oluşturulması: Ratlar her grupta 8'er adet olmak üzere dört gruba ayrıldı. Kontrol grubu ratlar standart rat pelet yemiyle beslenirken, Yüksek yağlı diyet (YYD) grubu ratlar yüksek yağlı diyet ile beslendi. YYD+Mate grubu ratlar ise yüksek yağlı diyet ile birlikte Mate yaprağı çayı günlük orogastrik gavaj ile verildi. Mate grubu 
ratlara, standart pelet yem ile birlikte Mate yaprağı çayı günlük orogastrik gavaj ile verildi. Çalışmaya 8 hafta süreyle devam edildi.
Denemenin 0., 28. ve 60. günlerinde ratlar tartıldı ve açlık kan glukoz düzeyleri ölçüldü.

Tablo 2. Mate çayının bazı serum biyomarkırları üzerine etkisi.

\begin{tabular}{lcccc}
\hline Testler & \multicolumn{4}{c}{ Gruplar } \\
\cline { 2 - 5 } & Kontrol $(\mathbf{n}=\mathbf{8})$ & YYD $(\mathbf{n}=\mathbf{8})$ & YYD+M $(\mathbf{n}=\mathbf{8})$ & $\mathbf{M}(\mathbf{n}=\mathbf{8})$ \\
\hline ALT (U/L) & $32.75 \pm 0.86$ & $64.33 \pm 4.78^{\mathrm{a}}$ & $44.20 \pm 3.40^{\mathrm{ab}}$ & $36.50 \pm 1.56$ \\
AST (U/L) & $86.25 \pm 3.12$ & $144.34 \pm 10.36^{\mathrm{a}}$ & $120.10 \pm 5.41^{\mathrm{ab}}$ & $85.25 \pm 2.60$ \\
GGT (U/L) & $4.00 \pm 0.40$ & $9.67 \pm 0.88^{\mathrm{a}}$ & $6.20 \pm 0.38^{\mathrm{ab}}$ & $3.75 \pm 0.25$ \\
ALP (U/L) & $199.00 \pm 17.56$ & $416.84 \pm 34.40^{\mathrm{a}}$ & $259.40 \pm 26.37$ ab & $204.00 \pm 12.74$ \\
LDH (U/L) & $519.25 \pm 150.19$ & $1055.67 \pm 96.05^{\mathrm{a}}$ & $658.80 \pm 42.63$ ab & $487.50 \pm 75.05$ \\
Kolesterol (CHOL) (mg/dL) & $52.50 \pm 0.65$ & $82.00 \pm 1.46^{\mathrm{a}}$ & $63.60 \pm 4.18^{\mathrm{ab}}$ & $51.50 \pm 2.10$ \\
LDL- kolesterol (mg/dL) & $22.43 \pm 1.09$ & $39.52 \pm 1.48^{\mathrm{a}}$ & $28.17 \pm 1.43^{\mathrm{ab}}$ & $21.15 \pm 1.36$ \\
HDL- kolesterol (mg/dL) & $24.73 \pm 1.30$ & $15.50 \pm 2.63^{\mathrm{a}}$ & $21.40 \pm 3.11^{\mathrm{ab}}$ & $25.10 \pm 1.36$ \\
Trigliserid (mg/dL) & $103.75 \pm 14.43$ & $216.00 \pm 43.16^{\mathrm{a}}$ & $176.40 \pm 14.42^{\mathrm{ab}}$ & $120.75 \pm 5.33$ \\
Glukoz (mg/dL) & $109.75 \pm 7.53$ & $334.50 \pm 15.25^{\mathrm{a}}$ & $215.10 \pm 10.70^{\mathrm{ab}}$ & $106.75 \pm 4.20$
\end{tabular}

a: Kontrol grubu ile karşılaştırıldığında $\mathrm{P}<0.05$.

b: YYD grubu ile karşılaştırldığında $P<0.05$.

Tablo 3. Grupların günlere göre kan glukoz $(\mathrm{mg} / \mathrm{dL})$ düzeyleri ile standart hataları.

\begin{tabular}{ccccc}
\hline Glukoz & \multicolumn{5}{c}{ Gruplar } & $\mathbf{M}(\mathbf{n}=8)$ \\
\cline { 2 - 5 } & Kontrol $(\mathbf{n}=8)$ & YYD $(\mathbf{n}=8)$ & YYD+M $(\mathbf{n}=8)$ & $107.50 \pm 3.07$ \\
\hline 1.GÜN & $109.25 \pm 4.11$ & $100.50 \pm 3.64$ & $99.48 \pm 2.98$ & $112.00 \pm 19.41$ \\
$28 . G U ̈ N$ & $108.00 \pm 35.54$ & $296.75 \pm 22.02^{\mathrm{a}}$ & $208.50 \pm 19.52^{\mathrm{ab}}$ & $116.75 \pm 20.23$ \\
60.GÜN & $119.75 \pm 29.58$ & $365.75 \pm 13.50^{\mathrm{a}}$ & $223.37 \pm 16.38^{\mathrm{ab}}$ & \\
\hline
\end{tabular}

a: Kontrol grubuna göre fark istatistiksel açıdan anlamlıdır $(P<0.05)$.

b: YYD grubuna göre fark istatistiksel açıdan anlamlıdır $(P<0.05)$.

Tablo 4. Grupların günlere göre canlı ağırlık ortalamaları (gr).

\begin{tabular}{lcccc}
\hline & \multicolumn{4}{c}{ Gruplar } \\
\cline { 2 - 5 } & Kontrol $(\mathbf{n = 8})$ & $\begin{array}{c}\text { YYD (n=8) } \\
\text { Ortalama } \pm \text { SD }\end{array}$ & YYD+M (n=8) & M (n=8) \\
\hline 1. Gün & $283.00 \pm 23.56$ & $284.50 \pm 11.20$ & $277.75 \pm 12.61$ & $281.50 \pm 19.50$ \\
28.GÜN & $299.75 \pm 21.33$ & $325.00 \pm 11.30^{\mathrm{a}}$ & $303.37 \pm 10.66^{\mathrm{b}}$ & $294.50 \pm 16.05^{\mathrm{b}}$ \\
60.GÜN & $322.50 \pm 17.87$ & $395.37 \pm 10.21^{\mathrm{a}}$ & $349.10 \pm 11.82^{\mathrm{b}}$ & $326.50 \pm 12.18^{\mathrm{b}}$ \\
\hline
\end{tabular}

a: Kontrol grubu ile karşılaştırıldığında $\mathrm{P}<0.05$.

b: YYD grubu ile karşılaştırldığında $P<0.05$.

Biyokimyasal analizler: Deneme sonunda tüm ratlar $50 \mathrm{mg} / \mathrm{kg}$ Ketamine hidroklorit+10 mg/kg dozunda Xylazine hidroklorit anestezisi altında exsanguninasyon yöntemi ile sakrifiye edildi. Tüm hayvanlardan intrakardiyak yoldan kanlar alındı ve kan serumları çıkarılarak Alanin transaminaz (ALT), Aspartik transaminaz (AST), Alkalen fosfataz (ALP), Laktat dehidrogenaz (LDH) ve Gama glutamil transferaz (GGT), Trigliserit, Kolesterol ( $\mathrm{CHOL}$ ), HDL-kolesterol ve LDL-kolesterol düzeyleri Biyokimya otoanalizöründe Abott marka ticari kitler kullanılarak çalışıldı.

Histopatolojik inceleme: Ratların nekropsileri yapılarak alınan karaciğer doku örnekleri \%10'luk tamponlu formaldehit solüsyonunda 72 saat süreyle fikse edildi. Rutin takip işlemi kapsamında; doku örnekleri alkol serilerinden geçirilerek dehidrasyonları; ksilol serilerinden geçirilerek şeffaflandırılmaları sağlandı ve daha sonra parafinde bloklandı. Bu bloklardan mikrotomda (Leica RM 2135) $4 \mu \mathrm{m}$ kalınlığında alınan kesitler Hematoksilen-Eozin (H.E.) boyama tekniğine göre boyanarak ışık mikroskobunda (Nikon 80i-DS-RI2) incelendi.

İstatiksel analiz: Biyokimyasal analiz sonuçları, merkezi eğilim ve yayılım ölçülerinden olan ortalama ve standart sapma (X \pm SD) ile değerlendirildi. Grup ortalamaları ve canlı ağırlıklar arasındaki farkın anlamlılığı ise tek taraflı Varyans Analizi ile (Oneway ANOVA) test edildi. Tüm istatistik analizlerde SPSS-15 paket programından yararlanıldı (SPSS Inc., Chicago, IL, USA). 


\section{Bulgular}

Histopatolojik bulgular: Karaciğer dokusunun mikroskobik görünümü Şekil 1 (A-D)'de sunulmuştur. Kontrol grubu (Şekil 1A) ile sadece Mate verilen gruba (Şekil 1D) ait ratların karaciğer dokusunda herhangi bir morfolojik değişikliğe rastlanılmamıştır. Bu grupların karaciğerlerinde; hepatositler ve portal alanların yapıları normal görünümde ve hepatositler de vena centralis çevresinde düzenli remark kordonları şeklinde orgnizasyona sahipti. Remark kordonları arasında bulunan sinuzoidler normal görünüm arzetmekteydi. YYD grubundaki ratların karaciğerlerinde ise özellikle sentrilobuler ve midzonal bölgelerdeki hepatositlerde yă dejenerasyonu, bazı hepatositlerde de parankim dejenerasyonu görüldü. Dejenerasyona uğrayan bazı hepatositlerin çekirdeklerinde piknotik değişkliklerin olduğu koagulasyon nekrozları tesbit edildi. Ayrıca sinüzoidal aralıklarda daralma ve Remark kordon yapısında dissosiasyon vardı (Şekil 1B). YYD+M grubundaki ratların karaciğerinde ise; sentrilobuler ve midzonal bölgelerdeki hepatositlerde nadiren yağ dejenerasyonuna ve hafif düzeyde parankim dejenerasyonuna rastlanıldı. Bu gruptaki ratların karaciğerleri normal histolojik yapıya yakın bir görüntü arzetmekteydi (Şekil 1C).
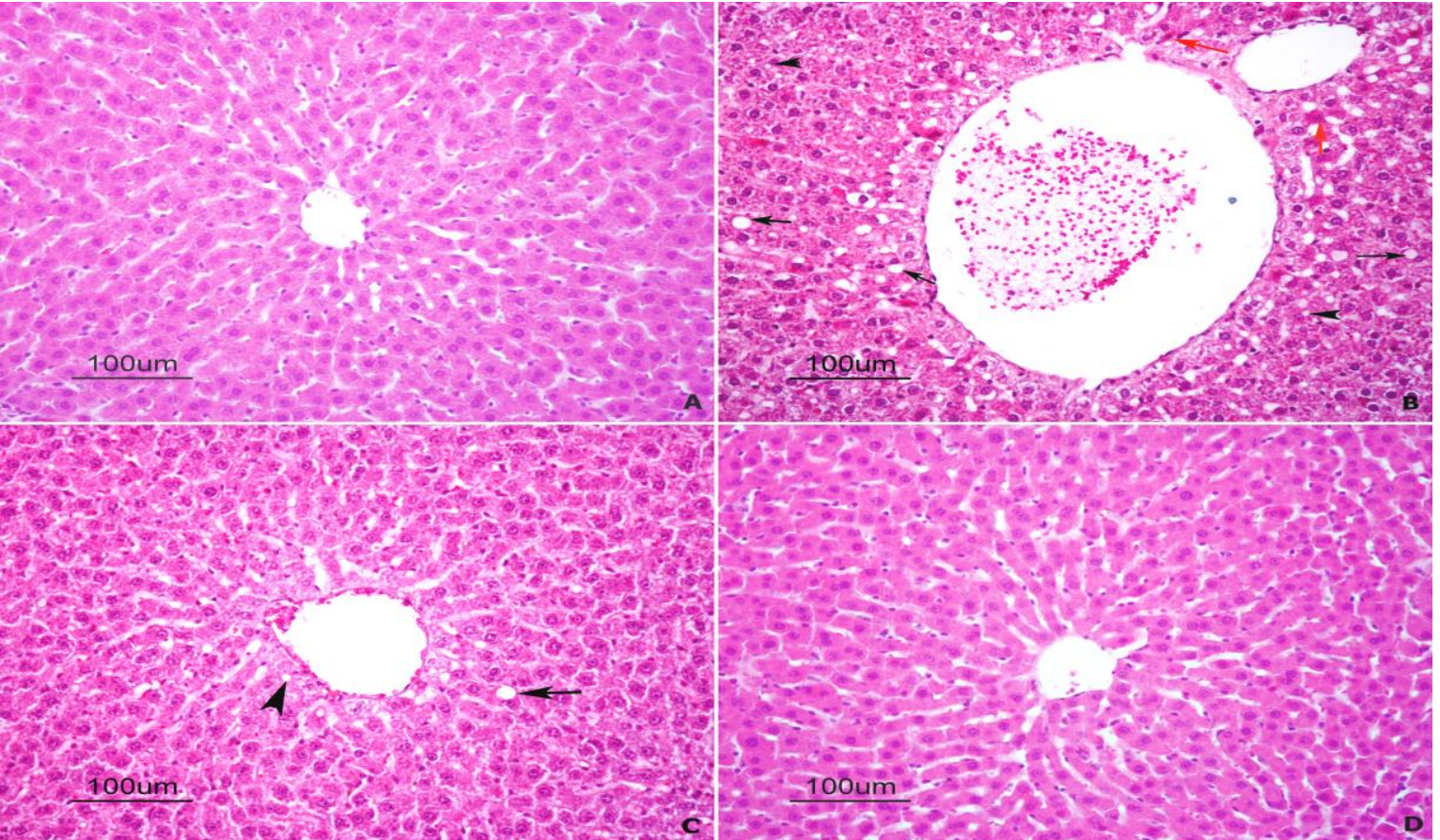

Şekil 1 (A-D). Karaciğerin mikroskobik görünümü. A: Kontrol Grubu: Karaciğerin normal histolojik görünümü, H.E. Bar=100 $\mu \mathrm{m}$. B: YYD Grubu: Sentrilobüler hepatositlerin sitoplazmalarında farklı büyüklüklerde yağ birikimleri (oklar ve ok başları) ve bazı hepatositlerde koagulasyon nekrozu (kırmızı ok), hidropik dejenerasyon ve sinüzoidlerde daralma H.E. Bar=100 $\mu \mathrm{m}$. C: YYD+M Grubu: Hepatositlerin sitoplazmalarında farklı büyüklüklerde çok nadir yağ birikimleri (ok ve ok başı). H.E. Bar=100 $\mu \mathrm{m}$. D: Mate Grubu: Karaciğerin normal histolojik görünümü, H.E., Bar $=100 \mu \mathrm{m}$.

Biyokimyasal bulgular: Deneme sonunda kontrol ve deney gruplarının alanin transaminaz (ALT), aspartik transaminaz (AST), alkalen fosfataz (ALP), laktat dehidrogenaz (LDH) ve gama glutamil transferaz (GGT), kolesterol, trigliserit ve HDL serum düzeyleri Tablo $2^{\prime}$ de, belirli günlere ait kan glukoz düzeyleri Tablo 3'de sunulmuştur.

Canlı ağırlık artışı değişimleri: Kontrol ve deney gruplarının günlere göre canlı ağırlık ortalamaları ile standart hataları Tablo 4'de sunulmuştur.

\section{Tartışma ve Sonuç}

Modern toplumlarda en sık görülen sağlık sorunlarından biri olan obezite, gelişmiş ve ülkemizin de dahil olduğu gelişmekte olan ülkelerde, epidemik boyutlara ulaşan ve sıklığı giderek artan ve küresel ölçekte önemli bir halk sağlığı sorunu olarak ortaya çıkan bir problemdir (Çayır ve ark., 2011). Obezite basit olarak enerji alımı ve harcanması arasındaki dengesizlikle bağlantılı olarak düşünülür. Bununla birlikte, 
yapılan araştırmalar genetik, fizyolojik ve davranış faktörlerinin de obezitenin etiyolojisinde rol oynadığı gösterilmiştir (Wilborn ve ark., 2005). Obezite kalp, karaciğer, böbrek ve pankreas gibi birçok organın lipidle infiltre olmasına neden olmaktadır (Fraulob ve ark., 2010).

Yüksek yağlı diyetle beslenmenin obezite ile çok yakından ilişkili olduğu bildirilmektedir (Dyck, 2000). Xu ve ark. (2010)'nın ratlarda yaptıkları bir araştırmada, \%52'si karbonhidratlar, \%30'u yağlar ve $\% 8^{\prime} i$ proteinden yüksek yağıı diyetle, \%67 karbonhidrat, \%10 yağ ve \%23 protein içeren kontrol diyetinin etkilerini incelemişler ve yüksek yağlı diyetle ile beslenen ratların vücut ağırlığındaki artışın kontrol grubuna göre istatistiksel açıdan önemli olduğunu belirtmişlerdir. Woods ve ark. (2004), enerjinin $\% 45$ 'ni, Briaud ve ark. (2002) ise enerjinin \%58'ni yağdan sağlanacak şekilde beslenen ratlarda kontrol grubuna göre canlı ağırlık artışı şekillendiğini bildirmişlerdir. Canlı ağırlıklardaki bu belirgin artışın, deneme süresine bağlı olarak besin ve enerji alımındaki artışla ilişkili olabileceği bildirilmiştir (Amin ve Nagy, 2009; Lee ve ark., 2006). Literatürde yağlı diyetle beslenen sıçanlarda canlı ağırlık artışı bildiren çalışmaların yanında (Altunkaynak ve ark., 2008; Cha ve ark., 2000), yağlı diyetle beslenmeye rağmen kilo alımının gerçekleşmediğini bildiren çalışmalar da mevcuttur (Omagari ve ark., 2008). Gao ve ark. (2002)'nın yaptığı çalışmada 6 ay süreyle $\% 45$ yağ içeren diyet ile beslenen sıçanların 4'ünde ağırlık artışıyla diyete bağlı obezite gelişirken, diğer 4 sıçanda ağırlık artışı gözlenmemiştir. Yapılan başka bir çalışmada ise 7 ay süre ile yüksek yağ içerikli diyet ile beslenen dişi sıçanlarda beslenme döneminin sonunda bazı sıçanlarda obezite gelişmesine rağmen, bazılarında da gelişmediği bildirilmiştir (Cattaneove ark., 1997). Haddad ve ark. (2009), 12 hafta boyunca yüksek yağlı sıvı diyet ile nonalkolik steatohepatit oluşturmayı hedefledikleri ratlarda $200 \mathrm{mg} / \mathrm{kg}$ gün dozda silibinin+fosfatidilkolin kompleksinin etkilerine bakmışlardır. Ratlarda silibinin verilen grubun son kilosunun kontrol grubuna göre anlamlı düzeyde düştüğünü, fakat aynı çalışmada yüksek yağlı diyet (YYD) grubuna göre silibinin grubunda deneme sonunda kiloda düşme olmakla birlikte anlamlı olmadığını belirtmişlerdir. Kapsaisinin de obez sıçanlarda vücut yağ miktarını ve vücut ağırlığnı azaltığı bildirilmiştir (Seyithanoğlu, 2015). Sunulan bu çalışmada YYD ile beslenen gruptaki kilo artışı, standart yem ile beslenen kontrol grubuna göre daha fazla olduğu tespit edildi $(P<0.05)$. Ayrıca YYD ile birlikte Mate verilen gruptaki sıçanların kilo artışı kontrol grubuna yakın olduğu görülerek yüksek yağlı beslemeyle birlikte Mate verilmesinin kilo artışını engellediği görülmüştür.

Karaciğerin histopatolojik incelemelerinde hepatositlerin \%5'ten fazlasında yağ vakuollerinin görülmesi karaciğer yağlanması olarak adlandırımaktadır (Adams, 2005). Yağlı karaciğer hastalığında basit steatozisten, steatohepatit, ileri derecede fibrozis ve siroza kadar klinikopatolojik bir tablo görülebilmektedir (Duvnjak ve ark., 2007; Tiniakos, 2010). Yağlanma sonucu oluşan inflamasyon ve fibrozis; oksidatif stres, mitokondrial fonksiyon bozuklukları, TNF- $\alpha$ gibi sitokinler ile adiponektin, leptin gibi hormonlar nedeniyle olduğu bildirilmektedir (Sonsuz, 2007). Ratlarda yapılan bir çalışmada (Xu ve ark., 2010), \%30'u yağlardan oluşan YYD ile beslenen ratlarda özellikle 24-48.haftalar arasında şiddetli steatozis, 16. haftadan itibaren ise hepatik fibrozis bulguları görülmeye başlandığı bildirilmiştir. Benzer şekilde \%30 yağ içeren yüksek yağlı diyet ile yapılan çalışmada da, yüksek yağlı diyet gruplarında; sinüzoidlerde dilatasyon, vena centralis ve portal aralıklarda mononükleer hücre infiltrasyonu ve fibrozis gözlendiği bildirilmiştir (Altunkaynak, 2005). Omagari ve ark. (2008)'nın, yüksek karbonhidratlı diyet ile yüksek yağlı diyeti karşılaştırmak amacıyla yaptıkları bir çalışmada her iki grupta da steatohepatitis ile ilgili steatozis, fibrozis ve inflamasyon bulgularına rastlanıldığı, ancak gruplar arasında hem kilo alımı açısından hem de karaciğerde histopatolojik olarak meydana getirdikleri steatoz sıklığı, lobüler inflamasyon, hepatosit balonlaşması ve fibroziste anlamlı bir farklılığın olmadığı bildirilmiştir. Sunulan bu çalışmada YYD grubundaki sıçanların tamamının karaciğer hepatositlerinde özellikle periasiner bölgede yağ vakuolleri ve hidropik dejenerasyondan dolayı sinüzoidal aralıklarda daralma ve Remark kordon yapısında dissosiasyon saptanması, fibrozis hariç yukarıda araştırmacıların bildirdikleri histopatolojik bulgular ile paralellik arzettiği ancak fibrozis götülmemesi yönünden paralellik arzetmediği görülmüştür.

Son yıllarda yağlı diyet uygulanarak oluşturulmuş deneysel yağlı karaciğer modeli çalışmalarında kullanılan bazı bitkilerin karaciğer yağlanmasını önlediği vurgulanmaktadır (Sharma ve ark., 2013). Kafein ve kafein benzeri etken maddeleri ihtiva eden bitkiler uygun dozda kullanıldıklarında kilo kontrolüne yardımcı olabildiği, örneğin yeşil çayın içerdiği epigallokateşingallat ve kafein nedeniyle yağ metabolizmasını arttırarak kilo kontrolüne neden olduğu bildirilmektedir (Sayın, 2012). Benzer şekilde Meksika biberi adıyla bilinen ve içinde kapsaisin bulunan preparatların da termojenezisi arttırarak kilo kontrollüne destek olabildiği 
görülmüştür (Aslan ve Orhan, 2010). Silybum marianum ekstresinin obezite üzerinde etkisinin araştırıldığı çalışmada yüksek yağlı diyetle beslenen ratlarda lipit metabolizmasını, leptin ve insülin düzeylerini düzenleyerek kandaki obeziteyle ilişkili parametreleri de düzeltmesiyle karaciğerde harabiyet gözlenmediği bildirilmiştir (Sayın, 2012). Ejaz ve ark. (2009)'nın yaptıkları çalışmada yağlı diyetle birlikte kurkumin uygulamasının farelerde hepatik steatozisi azaltığı gösterilmiştir. Sunulan bu çalışmada da YYD+M grubundaki sıçanların tamamının karaciğer hepatositlerinde YYD grubundakine oranla hafif derecede mikroveziküler yağlanma ve hidropik dejenerasyonla birlikte bazı hepatositlerde hafif düzeyde parankim dejenerasyonu görülmesi, karaciğerin normal histolojik yapısında görülen lopçuklu görünümü ile birlikte Remark kordon yapısının bozulmamış olması ve kordonlar arasındaki sinüzoidlerin normal histolojik yapıda olması, yangı hücreleri, fibrozis ve hepatositlerde nekroza rastlanılmaması; yüksek yağlı diyet ile birlike Mate verilmesinin karaciğerde meydana gelebilen hasarları önleyebildiği anlaşılmaktadır.

Yapılan çalışmalarda intraselüler enzimlerden $A L T, A S T, L D H$ ve GGT; hepatositlerdeki hasara bağlı olarak seruma salınmakta ve bu enzimlerin aktivitelerindeki artışın ise karaciğer hasarının göstergesi olduğu ileri sürülmektedir (Aras ve Ersen, 1992; El-Sakka ve ark., 2002). Obezite oluşturulan ratların karaciğerinde tespit edilen en yaygın biyokimyasal bulgular; ALT, AST, ALP ve GGT normal sınırın 2-3 katı kadar artışlardır (ElSakka ve ark., 2002). Silymarin ile yapılan bir çalışmada; hepatoselüler kansere bağlı artan trigliserid, LDL ve VLDL seviylerini gerilettiği ve azalan HDL düzeyini arttırdığı gösterilmiştir (Adams ve ark., 2005). Bir diğer çalışmada yüksek yağlı diyet grubunda trigliserid, total ve VLDL kolesterol düzeylerinde yükselme ve HDL kolesterol düzeyinde kontrol grubuna göre düşüşler gözlendiği, yüksek yağlı diyetle birlikte Achillea wilhelmsii ekstresi uygulaması ile trigliserid, total ve VLDL kolesterol düzeylerinde diyet grubuna göre düşüşler gözlendiği dolayısıyla bu bitki ektresinin kan lipitleri üzerinde düzenleyici bir rolü olduğu ifade edilmiştir (Suzergoz ve ark., 2013). Yüksek kolesterollü diyetle beslenen ratlarda silymarin (Adams ve ark., 2005) ve ginsengin (Altin ve ark., 2014) etkisinin araştırıldığı çalışmalarda yüksek oranda kolesterollü diyetle birlikte ginseng uygulamasının serum total kolesterol, LDLkolesterol ve trigliserid düzeyinde meydana gelen düşüşler ile serum HDL kolesterol düzeyinde artışlar görülmesi, bu bitkilerin lipid profili üzerine düzenleyici etkileri olabileceği sonucuna ulaşılmıştır. Sunulan çalışmada YYD grubu ile kontrol grubu arasında ALT, AST, ALP ve GGT değerleri karşılaştırıldığında; YYD grubunda istatistiksel olarak yüksek, YYD+Mate grubunda ise kontrol ile benzer ya da kontrole yakın değerler bulundu. Bu değerlerin YYD grubunda yüksek olması; bu grupta yağlanmanın/hasarın olduğunu, YYD ile birlikte Mate verilen grupta ise hepatositlerin bu yağlanmadan/hasardan kısmen korunduğunu göstermektedir. Mevcut çalışmada YYD modeli oluşturulan grupta serum kolesterol, $\mathrm{LDH}, \mathrm{HDL}$ ve trigliserid seviyelerinin de kontrol grubuna göre yüksek olduğu YYD ile birlikte Mate verilen grupta bu değerlerin kontrol grubuna yakın olduğu tespit edilmiştir. Bu biyokimyasal veriler doğrultusunda, YYD grubunda karaciğerde meydana gelen hasar nedeniyle serum enzimleri ve lipit profili biyomarkırlarının arttığı, fakat YYD+M grubunda Mate'nin hepatoprotektif ve antihiperlipidemik etkisi sayesinde karaciğer hasarlarının engellendiği söylenebilir.

Obezitenin en önemli bulgularından biri de santral yağ dağılımı kabul edilir. Santral yağ dağılımı obezite için önemli bir faktör olarak kabul edilirken glukoz dengesinin bozulmasında da önemli rol oynadığı düşünülmektedir. En önemli klinik bulgular arasında plazma serbest yağ asidi miktarında artış, karaciğer glukoz üretiminde artış ve periferik insülin direnci yer almaktadır (Reaven, 1998). Ratlar üzerinde yapılan çalışmalarda obeziteyle birlikte insülin direncinin artmasıyla serum glukoz düzeyinin de arttığı bildirilmiştir (Gelardi ve ark., 1990). Sunulan bu çalışmada serum glukoz düzeyinin YYD grubunda arttığı, YYD ile birlikte Mate verilen grupta serum glukoz düzeyinin kontrol grubuna göre yüksek ancak YYD grubuna göre daha düşük düzeyde olduğu görülmüştür.

Sonuç olarak, yüksek yağlı diyetle beslenen ratlarda Mate (Ilex paraguariensis) bitkisinin obezite oluşumu üzerine koruyucu etkisinin araştırıldığı bu çalışmada, bu bitkinin karaciğer yağlanmasını ve kilo artışını büyük oranda engellediği kanısına varıldı.

\section{Kaynaklar}

Adams LA, Lymp JF, St Sauver J, Sanderson SO, Lindor $K D$, Feldstein A, 2005: The natural history of nonalcoholic fatty liver disease: A population-based cohort study. Gastroenterol, 129, 113-21.

Adıyaman F, 2016: Dünya sağlık örgütü avrupa obezite ile mücadele Bakanlar konferansının öncesi ve sonrasında Obezitenin gazetelerde sunumu. Selçuk Üniv Iletişim Fak Akademik Derg, 9(3), 204-223.

Altin M, Keskin E, Uluisik D, 2014: Effects of ginseng on TNF- $\alpha$, leptin and plasma lipid levels of rats fed a cholesterol-rich diet. Turk J Sport Exe, 16(2), 59-62. 
Altunkaynak ME, Özbek E, Altunkaynak BZ, 2008: The effects of high-fat diet on the renal structure and morphometric parametric of kidneys in rats. J Anat, $212,845-852$.

Altunkaynak Z, 2005: Effects of High Fat Diet Induced Obesity on Female Rat Livers (A Histochemical Study). Eur J Gen Med, 2(3), 100-109.

Amin KA, Nagy MA, 2009: Effect of Carnitine and herbal mixture extract on obesity induced by high fat diet in rats. Diabetol Metab Syndr, 16, 1(1), 1-17.

Andersen T, Fogh J, 2001: Weight loss and delayed gastric emptying following a South American herbal preparation in overweight patients. J Hum Nutr Diet, 14(3), 243-250.

Anesini C, Turner S, Cogoi L, 2012: Study of the participation of caffeine and polyphenols on the overall antioxidant activity of mate (Ilex paraguariensis). Food Sci Technol, 45(2), 299-304.

Aras K, Ersen G, 1992: Klinik Biyokimya, Tas Kitapçılık Ltd. Şti, Ankara, 338.

Arçari D, Bartchewsky W, Tanila W, Oliveira KA, DeOliveira CC, Gotardo ÉM, Pedrazzoli J Jr, Gambero A, Ferraz LF, Carvalho Pde O, Ribeiro ML, 2011: Antiinflammatory effects of yerba mate extract (Ilex paraguariensis) ameliorate insulin resistance in mice with high fat diet-induced obesity. Mol Cell Endocrinol, 335(2), 110-115.

Arçari DP, Bartchewsky W, dos Santos TW, Oliveira KA, Funck A, Pedrazzoli J, de Souza MF, Saad MJ, Bastos DH, Gambero A, Carvalho PO, Ribeiro ML, 2009: Antiobesity effects of yerba maté extract (Ilex paraguariensis) in highfat diet-induced obese mice. Obesity, 17(12), 2127-2133.

Aslan M, Orhan N, 2010: Obezite Tedavisine Yardımcı Olarak Kullanılan Doğal Ürünler. Mised, 23-24, 91105.

Bastos DHM, Oliveira DD, Matsumoto RLT, Carvalho PO, Riberio ML, 2007: Yerba mate: pharmacological properties, research and biotechnology. Med Aromat Plant Sci Biotechnol, 1(1), 37-46.

Baytop T, 1994: Türkçe Bitki Adları Sözlüğü. Ankara. Türk Dil Kurumu Yayınları 140. Bell CG, Walley AJ, Froguel $P, 2005:$ The genetics of human obesity. Nat Rev Genet, 6, 221-34

Blumenthal M, 1998: The Complete German Comission E Monographs. Boston: Massachusetts, 167-168.

Bracesco N, Sanchez AG, Contreras V, 2001: Recent advances on llex paraguariensis research: Minireview. J Ethnopharmacol, 136(3), 378-384.

Briaud I, Kelpe CL, Johnson LM, 2002: Differential effects of hyperlipidemia on insulin secretion in islets of Langerhans from hyperglycemic versus normoglycemic rats. Diabetes, 51, 662-668.

Cattaneo L, De Gennaro Colonna V, Müller EE, Cochi D, 1997: Hypothalamopituitary-IGF-1 axis in female rats made obese by overfeeding. Life Sci, 61(9), 881889.

Cha MC, Chou CJ, Boozer CN, 2000: High-fat diet feeding reduces the diurnal variation of plasma leptin concentration in rats. Metabolism, 49, 503-507.

Çayır A, Atak N, Köse SK, 2011: Beslenme ve diyet kliniğine başvuranlarda obezite durumu ve etkili faktörlerin belirlenmesi. Ankara Üniversitesi Tıp Fakültesi Mecmuası, 64(1), 13-19.

Çubukçu B, Sarıyar G, Meriçli AH, 2002: Fitoterapi Yardımcı Ders Kitabı, İstanbul: İstanbul Üniversitesi Basım ve Yayınevi, 5.

Davis PH, 1967: Flora of Turkey and the East Aegean Islands. Edinburgh University Press, 2, 541-542.

De la Maza MP, Hirsch S, Petermann M, Suazo M, Ugarte G, Bunout D, 2000: Changes in microsomal activity in alcoholism and obesity. Alcohol Clin Exp Res, 24(5), 605-610.

Duvnjak M, Lerotić I, Baršić $N$, Tomašić $V$, Jukić LV, Velagić V, 2007. Pathogenesis and management issues for non-alcoholic fatty liver disease. World $J$ Gastroenterol, 13(34), 4539-4550.

Dyck DJ, 2000: Dietary fat intake, supplements and weight loss. Can J Appl Physiol, 25, 495-523.

Ejaz A, Wu D, Kwan P. Meydani M, 2009: Curcumin inhibits adipogenesis in 3T3-L1 adipocytes and angiogenesis and obesity in C57/BL mice. J Nutr, 139(5), 919-25.

El-Sakka S, Salem Eel-D, Abdel-Rahman MS, 2002: In vitro hepatotoxicity of alachlor and its by-product. J Appl Toxicol, 22, 31-35.

Evans WC, 2009. Trease and Evans Pharmacognosy (Eighth Edition). England: Elsevier Health Sciences, 410-411.

Filip R, Lotito SB, Ferraro G, Cesar GF, 2000: Antioxidant activity of Ilex paraguariensis and related species. Nutr Res, 20(10), 1437-1446.

Fraulob JC, Ogg-Diamantino R, Fernandes-Santos C, 2010: A mouse model of metabolic syndrome: insulin resistance, fatty liver and Non-Alcoholic Fatty Pancreas Disease (NAFPD) in C57BL/6 mice fed a high fat diet. J Clin Biochem Nutr, 46, 212-223

Gao J, Ghibaudi L, van Heek M, Hwa JJ, 2002. Characterization of diet-induced obese rats that develop persistent obesity after 6 months of highfat followed by 1 month of low-fat diet. Brain Res, 936, 87-90.

Gelardi NL, Cha CJM, Oh W, 1990: Glucose metabolism in adipocytes of obese offspring of mild hyperglycemic rats. Pediatr Res, 28(6), 641-645.

Gunbatar N, Bayiroglu F, 2015: The Effect of a Highly Saturated Fat Diet and Intermittent Fasting Diet on Experimental Colon Cancer Development and Some Serum Inflammation Markers in Rats, Adiponectin and Lipid Metabolism. Van Vet J, 26(3),123-127.

Haddad Y, Vallerand D, Brault A, Haddad PS, 2009: Antioxidant and Hepatoprotective Effects of. Silibinin in a Rat Model of Nonalcoholic Steatohepatitis. Oxford University Press, 35, 98-115.

LaGow B, 2004: PDR for Herbal Medicines (Third edition). Montvale, New Jersey. Thomson Medical Economics, 559-560.

Lee, JS, Lee MK, Ha TY, 2006: Supplementation of whole persimmon leaf improves lipid profiles and suppresses body weight gain in rats fed high-fat diet. Food Chem Toxicol, 44, 1875-1883.

Martin JGP, Porto E, de Alencar SM, da Gloria EM, Correa CB, Cabral ISR, 2013: Antimicrobial activity of yerba mate (Ilex paraguariensis A.St.-Hil.) against food pathogens. Rev Argent Microbiol, 45, 93-98. 
Mejia E, Songa Y, Hecka C, 2010: Yerba mate tea (Ilex paraguariensis): Phenolics, antioxidant capacity and in vitro inhibition of colon cancer cell proliferation. $J$ Funct Foods, 2, 23-34.

Newall CA, Anderson LA, Phillipson JD,1996: Herbal Medicines. Mate. London: The Pharmaceutical Press, 189-190.

Omagari K, Kato S, Tsuneyama K, 2008: Effect of a LongTerm High-Fat Diet and Switching from a High-Fat to Low-Fat, Standart Diet on Hepatic Fat Accumulation in Sprague-Dawley Rats. Dig Dis Sci, 53, 3206-3212.

Padwal RS, Majumdar SR, 2007: Drug treatments for obesity: orlistat, sibutramine, and rimonabant. Lancet, 369(9555), 71-7.

Pagotto U, Vanuzzo D, Vicennati V, 2008: Pharmacological therapy of obesity. G Ital Cardiol (Rome), 9(4), 83-93.

Ramirez-Mares MV, Chandra S, de Mejia EG, 2004: In vitro chemopreventive activity of Camellia sinensis, llex paraguariensis and Ardisia compressa tea extracts and selected polyphenols. Mutat Res 554(1), 53-65.

Reaven GM, 1998: Role of insulin resistance in human disease. Diabetes, 37, 1595-1607.

Reis EDE, Neto FWS, Cattani VB, Peroza LR, Busanello A, Leal $C Q$, Boligon $A A$, Lehmen TF, Libardoni $M$, Athayde ML, Fachinetto R, 2014: Antidepressant-like effect of Ilex paraguariensis in rats. Biomed Res Int, Volume 2014, Article ID 958209, 9 pages, http://dx.doi.org/10.1155/2014/958209.

Sayın, FK, 2012: Silybum marianum ekstresinin yüksek yağlı diyetle beslenen ratlarda insülin rezistansı, karaciğer fonksiyonları, lipit düzeyleri ve leptin seviyesi üzerine etkilerinin araştırılması. Doktora Tezi, SÜ Tıp Fakültesi, Konya.

Seyithanoğlu M, 2015: Deneysel yüksek yağlı beslenme modelinde kurkumin ve kapsaisin uygulamasının karaciğer yağlanması üzerine etkileri. Doktora Tezi, iü Tıp Fakültesi, İstanbul,
Sharma SK, Vij AS, Sharma M, 2013: Mechanisms and clinical uses of capsaicin. Eur J Pharmacol, 15, 720 (1-3), 55-62.

Sonsuz A, 2007: Nonalkolik karaciğer yağlanması. iÜ Cerrahpaşa Tıp Fakültesi Sürekli Tıp Eğitimi Etkinlikleri, 58, 91-98.

SPSS Inc. Released 2007. SPSS for Windows, Version 15.0. Chicago, IL, USA.

Suzergoz F, Çinar S, Oktay R, Karakus F, Gurol AO, 2013: Effect of Achillea wilhelmsii Extract Intake Upon Blood Lipid Profile, Hematologic and Immunologic Parameters in the Rat. Food Agric Immunol, DOI:10.1080/09540105.2013. 864605.

Tiniakos DG, 2010: Nonalcoholic fatty liver disease/nonalcoholic steatohepatitis: histological diagnostic criteria and scoring systems. Eur J Gastroenterol Hepatol, 22(6), 643-50.

Vieira MA, Rovaris AA, Maraschin M, De Simas $\mathrm{KN}$, Pagliosa CM, Podestá R, Amboni RD, Barreto $\mathrm{PL}$, Amante ER, 2008: Chemical characterization of candy made of Erva-Mate (Ilex paraguariensis A.St.Hil.) residue. J Agric Food Chem, 56 (12), 4637-42.

Wichtl M, 2004: Herbal Drugs and Phytopharmaceuticals: A Handbook for Practice on A Scientific Basis. Stuttgart, CRC press, 319-321.

Wilborn C, Beckham J, Campbell B, Harvey T, Galbreath M, La Bounty P, Nassar E, Wissman J, Kreider R, 2005: Obesity: Prevalence, Theories, Medical Consequences, Management, and Research Directions. J Int Soc Sports Nutr, 2(2), 4-31.

Woods, SC, D'alessio DA, Tso P, 2004: Consumption of a high-fat diet alters the homeostatic regulation of energy balance. Physiol Behav, 83(4), 573-578.

Xu JZ, Fan JG, Ding XD, 2010: Characterization of HighFat, Diet Induced, Non-alcoholic Steatohepatitis with Fibrosis in Rats. Dig Dis Sci, 55(4), 931-940.

*Yazışma adresi: Ahmet UYAR

Mustafa Kemal Üniversitesi, Veteriner Fakültesi, Patoloji Anabilim Dalı, 31040 Antakya/Hatay, Turkiye.

E-mail: uyarahmet@hotmail.com. 